\title{
APLIKASI FUZZY DATABASE MODEL TAHANI DALAM MEMBERIKAN REKOMENDASI PEMBELIAN RUMAH BERBASIS WEB
}

\author{
Rusdi Efendi ${ }^{1}$, Ernawati ${ }^{2}$, Rahmi Hidayati ${ }^{3}$ \\ ${ }^{1,2,3}$ Program Studi Teknik Infomatika, Fakultas Teknik, Universitas Bengkulu. \\ Jl. WR. Supratman Kandang Limun Bengkulu 38371A INDONESIA \\ (telp: 0736-341022; fax: 0736-341022) \\ ${ }^{1}$ r_efendidyahoo.com \\ w_ier_na@yahoo. com
}

Abstrak: Fuzzy database model Tahani merupakan salah satu metode yang dapat digunakan pada proses pengambilan keputusan. Dalam penelitian ini, aplikasi fuzzy database model Tahani dibangun untuk membantu pihak developer perumahan dalam memberikan rekomendasi rumah kepada konsumen, sehingga konsumen dapat memilih rumah sesuai dengan kriteria yang dipilihnya dengan lebih cepat dan mudah. Pada aplikasi yang telah dibangun, hasil rekomendasi rumah didasarkan pada nilai derajat keanggotaan dan fire strength (nilai kebenaran) dari proses perhitungan di dalam aplikasi tersebut. Hasil dari aplikasi ini yaitu berupa lima nilai terbaik hasil rekomendasi rumah dan diurutkan berdasarkan nilai tertinggi sampai dengan terendah. Untuk pengujian terhadap aplikasi yang dibangun, dilakukan dengan dua cara yaitu uji kelayakan sistem dan perbandingan hasil perhitungan secara manual terhadap perhitungan dengan menggunakan aplikasi. Dari kedua pengujian tersebut diperoleh hasil bahwa aplikasi ini telah layak digunakan oleh PT. Cipta Graha Sentosa Bengkulu dan hasil pengujian sistem pada aplikasi sama dengan perhitungan secara manual.

Kata kunci: Fuzzy Database, Tahani, Waterfall, Fire Strength, Rekomendasi Rumah.

Abstract: Fuzzy database models Tahani is one of method that can be used in decisionmaking process. In this research, application of fuzzy database models Tahani was built to help the developer of housing in giving recommendations of house to consumers, so that consumers can choose the house in accordance with the criteria more quickly and easily. In applications that have been implemented, result of house recommendation is based on the value of membership degree and fire strength (truth value) from the calculation process in the application. System development method that is used to build these applications is the waterfall model. While at the system analysis and design phase done by structural approach. The result of this application is in the form of five best value of house recommendation and sorted by highest to the lowest value. To test the application built, done in two ways, they are test feasibility of system and comparison of calculations result manually to calculation by using application. Of the two test results obtained that this application has been fit for use by the PT. Cipta Graha Sentosa Bengkulu and results of system testing at application are equal to the calculation manually.
Keywords: Fuzzy Database, Tahani, Waterfall, Fire Strength, House Recommendation.

\section{PENDAHULUAN}

Perusahaan yang bergerak di bidang properti memiliki data dan spesifikasi rumah yang bermacam-macam, sehingga kadang kala pengembang atau developer perumahan mengalami kesulitan dalam memberikan rekomendasi rumah kepada konsumen. Oleh karena itu, developer perumahan perlu diiringi oleh perkembangan teknologi komputer untuk dapat memenuhi kebutuhan para konsumen.

Para konsumen pembeli perumahan pada umumnya selalu memiliki pertimbangan dari kriteria-kriteria perumahan yang mereka inginkan sebelum menentukan rumah yang ingin dibeli. Dalam memilih kriteria perumahan yang diinginkan, terkadang seorang konsumen kurang 
mengetahui nilai/ ukuran yang sebenarnya. Kesamaran dari pertimbangan kriteria konsumen tersebut dapat dituangkan ke dalam suatu konsep logika fuzzy dengan menggunakan database yang mampu menangani kriteria-kriteria yang bersifat samar. Adapun database yang mampu menangani data dari proses query yang bersifat samar bernama fuzzy database Model Tahani, karena model database fuzzy Tahani merupakan database yang mampu memetakan suatu input data yang bersifat angka (crisp) menjadi data yang bersifat linguistik (samar)

Dengan aplikasi yang akan dibangun ini, konsumen dapat lebih mudah menentukan kriteria rumah yang ingin dibelinya, karena tidak perlu mengetahui ukuran/ nilai dari kriteria rumah secara pasti. Adapun objek masalah yang diselesaikan pada penelitian ini adalah pembelian rumah pada perumahan yang ada di kota Bengkulu, contoh kasusnya yaitu PT. Cipta Graha Sentosa Bengkulu. Dikarenakan perumahan PT. Cipta Graha Sentosa Bengkulu memiliki tiga lokasi sehingga data-data yang berhubungan pada sistem ini harus terintegrasi, selain itu dengan semakin luasnya penggunaan media internet maka sistem ini dibuat berbasis web.

Berdasarkan latar belakang di atas, maka peneliti tertarik untuk membangun sebuah “Aplikasi Fuzzy Database Model Tahani dalam Memberikan Rekomendasi Pembelian Rumah Berbasis Web" dengan Studi Kasus pada PT. Cipta Graha Sentosa Bengkulu. Sistem ini diharapkan dapat memberikan kontribusi kepada developer perumahan dalam memberikan rekomendasi rumah kepada konsumen sebagai bahan pertimbangan dalam membeli rumah, akan tetapi keputusan akhir tetap konsumen sendiri yang menentukan.

\section{LANDASAN TEORI}

Logika fuzzy mewakili suatu arti harafiah dalam bahasa Indonesia adalah samar atau kabur. Logika fuzzy (logika kabur) adalah metodologi untuk menyatakan hukum operasional dari suatu sistem dengan ungkapan bahasa, bukan dengan persamaan matematis. Menurut Kusumadewi dalam [1] "Logika fuzzy adalah suatu cara yang tepat untuk memetakan suatu ruang input ke dalam suatu ruang output".

Dalam logika klasik, keanggotaan suatu elemen dalam himpunan dipresentasikan dengan 0 bila bukan anggota dan 1 bila merupakan anggota. Jadi himpunannya adalah $\{0,1\}$. Sedangkan pada logika fuzzy memiliki banyak nilai. Tidak seperti elemen yang dikategorikan $100 \%$ semuanya benar atau salah, fuzzy membaginya dalam derajat keanggotaan dan derajat kebenaran pada interval $[0,1]$, yaitu: sesuatu yang dapat menjadi sebagian benar dan sebagian salah pada waktu yang sama. Jadi Logika fuzzy adalah superset (bagian yang melingkupi) logika boolean yang dikembangkan untuk menangani suatu komponen atau informasi secara keseluruhan [2].

\section{A. Fuzzy Database}

Basisdata (database) merupakan kumpulan dari data yang saling berhubungan satu dengan yang lainnya, tersimpan di perangkat keras komputer dan digunakan perangkat lunak untuk memanipulasinya [3]. Basisdata bertujuan untuk mengatur data sehingga diperoleh kemudahan, ketepatan, dan kecepatan dalam mengambil kembali data.

Sistem basis data (database system) adalah suatu sistem informasi yang mengintegrasikan kumpulan data yang saling berhubungan satu dengan yang lainnya dan membuatnya tersedia untuk beberapa aplikasi dalam suatu organisasi [3]. 
Jadi, tidak ada sistem informasi yang dibuat/dijalankan tanpa adanya basis data.

Sedangkan pengertian fuzzy database system adalah suatu sistem basis data yang menggunakan teori himpunan fuzzy dalam menghasilkan informasi. Keuntungan fuzzy database sistem adalah sebagai berikut:

1. Fuzzy database memungkinkan penanganan data secara alami karena mengikuti pikiran manusia.

2. Digunakannya logika fuzzy dalam melakukan pencarian data sehingga menghasilkan data yang sistematis.

3. Menyediakan lingkungan basis data untuk menangani data yang masih samar.

Fuzzy database terbagi atas:

\section{a. Fuzzy Database Model Tahani \\ b. Fuzzy Database Model Umano}

\section{B. Fuzzy Database Model Tahani}

Sebagian besar basis data standar diklasifikasikan berdasarkan bagaimana data tersebut dipandang oleh user. Basis data fuzzy model Tahani masih tetap menggunakan relasi standar, hanya saja model ini menggunakan teori himpunan fuzzy untuk mendapatkan informasi pada query-nya. Jadi, data awal yang diproses adalah data yang memiliki nilai crisp (pasti/ jelas keberadaannya), dan ketika hendak melakukan proses pencarian data yang bersifat samar maka proses tersebut yang dinamakan proses fuzzy query melalui fuzzy database model Tahani.

Ide dari sistem fuzzy database model Tahani adalah mendefinisikan konsep dari relasi fuzzy dalam sebuah database sistem dengan menggunakan derajat keanggotaan. Contoh kasus yang dapat diselesaikan dengan fuzzy database model Tahani adalah aplikasi fuzzy database system model Tahani untuk memberikan rekomendasi pilihan HP bagi konsumen berdasarkan kriteria-kriteria yang diinginkan oleh konsumen. Pada kasus tersebut, outlet HP memiliki data HP yang tersimpan pada tabel. Atribut yang ada pada setiap tipe HP berupa: harga, dimensi, berat, dan phonebook_memory; serta ada tidaknya fasilitas WAP seperti pada Tabel 1 DT_HP pada Outlet Penjualan HP [3].

Tabel 1 Contoh Tabel DT_HP pada Outlet Penjualan HP

\begin{tabular}{|c|c|c|c|c|c|c|}
\hline No. & Type & Harga (Rp) & $\begin{array}{c}\text { Dimensi } \\
\left(\mathrm{mm}^{3}\right)\end{array}$ & $\begin{array}{l}\text { Berat } \\
\text { (gram) }\end{array}$ & $\begin{array}{c}\text { Phonebook_ } \\
\text { memory }\end{array}$ & $\begin{array}{l}\text { Ada } \\
\text { wap }\end{array}$ \\
\hline 1 & 6898 & 2.100 .000 & 752.000 & 82 & 50 & 1 \\
\hline 2 & A3618 & 7.250 .000 & 114.774 & 86 & 100 & 0 \\
\hline 3 & C35 & 700.000 & 119.416 & 116 & 199 & 1 \\
\hline 4 & $\mathrm{C} 45$ & 730.000 & 115.322 & 107 & 50 & 1 \\
\hline 5 & CL50 & 2.500 .000 & 62.634 & 79 & 500 & 1 \\
\hline 6 & CMD J5 & 1.440 .000 & 129.168 & 81 & 500 & 1 \\
\hline 7 & $\mathrm{~N} 3350$ & 925.000 & 126.507 & 108 & 250 & 1 \\
\hline 8 & $\mathrm{~N} 5510$ & 1.150 .000 & 217.616 & 155 & 250 & 1 \\
\hline 9 & N8210 & 1.800 .000 & 78.030 & 79 & 250 & 1 \\
\hline 10 & N8910 & 6.000 .000 & 94.760 & 110 & 500 & 1 \\
\hline 11 & SG 2000 & 2.500 .000 & 48.100 & 70 & 250 & 1 \\
\hline 12 & T190 & 750.000 & 63.600 & 101 & 300 & 1 \\
\hline 13 & $\mathrm{~T} 20$ & 800.000 & 152.712 & 128 & 199 & 0 \\
\hline 14 & T200 & 1.300 .000 & 100.800 & 85 & 300 & 1 \\
\hline 15 & T29s & 900.000 & 143.521 & 95 & 250 & 1 \\
\hline
\end{tabular}

Jika dengan menggunakan basisdata standar, kita dapat mencari data-data HP dengan spesifikasi tertentu dengan menggunakan query. Misal kita ingin mendapatkan informasi tentang tipe HP yang harga nya kurang dari Rp. 1.000.000,- tetapi beratnya kurang dari atau sama dengan 100 gram, maka kita bisa menuliskan suatu query :

SELECT TYPE FROM DT_HP WHERE (Harga < 1000000) and (Berat $\leq 100)$.

Sehingga muncul tipe HP T29s, sedangkan tipe HP T190 yang harganya kurang dari Rp. 1.000.000,- tidak terpilih padahal beda beratnya selisih 1 gram dari krtieria yang ditentukan. Disini berarti pada basisdata standar, adanya perubahan kecil saja mengakibatkan perbedaan kategori yang cukup signifikan antara HP yang terpilih dan tidak terpilih.

Agar konsumen lebih mudah dalam memberikan kriteria yang diinginkan, maka penyampaian informasi tentang kriteria suatu 
atribut direpresentasikan menggunakan bahasa sehari-hari/ variabel lingusitik. Pada kasus penjualan HP, seorang konsumen ingin mencari informasi mengenai tipe HP yang sesuai dengan kriteria yang diinginkannya, adapun datanya menggunakan bahasa sehari-hari (bersifat samar). Pada basisdata fuzzy Tahani, awalnya dibentuk suatu himpunan fuzzy dengan fungsi keanggotaannya. Untuk menilai tipe HP yang diinginkan maka dibentuklah beberapa kategori yang perlu dipertimbangkan dengan himpunan yang dimiliki pada masing masing kriiteria. Kriteria-kriteria tersebut adalah sebagai berikut [2]:

a. Harga HP (MURAH, SEDANG, dan MAHAL)

b. Dimensi (KECIL, SEDANG, dan BESAR)

c. berat (RINGAN, SEDANG, dan BERAT)

d. phonebook memory (SEDIKIT, SEDANG, dan BANYAK)

Misalkan kita mengkategorikan harga HP ke dalam himpunan: MURAH, SEDANG, dan MAHAL. Himpunan MURAH dan MAHAL menggunakan pendekatan fungsi keanggotaan berbentuk bahu, sedangkan himpunan SEDANG menggunakan pendekatan fungsi keanggotaan berbentuk segitiga. Funsi keanggotaan harag $\mathrm{Hp}$ terlihat pada gambar 1 .

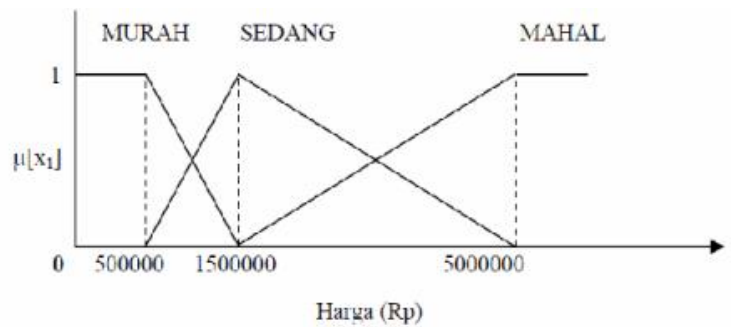

Gambar 1 Fungsi Keanggotaan pada Variabel Harga
Fungsi keanggotaan variabel harga dirumuskan sebagai berikut:

$$
\begin{aligned}
& \mu I I \text { arg } a_{\text {MURAH }}\left[x_{1}\right]-\left\{\begin{array}{ccc}
1 & \rightarrow & x_{1} \leq 500000 \\
\frac{1500000-x_{1}}{1000000} & \rightarrow & 500000 \leq x_{1} \leq 1500000 \\
0 & \rightarrow & x_{1} \geq 1500000
\end{array}\right. \\
& \mu H \text { ang } a_{\text {SED } A N G}\left[x_{1}\right]=\left\{\begin{array}{ccc}
0 & \rightarrow & x_{1} \leq 500000 \text { atou } x_{1} \geq 5000000 \\
\frac{x_{1}-500000}{1000000} & \rightarrow & 500000 \leq x_{1} \leq 1500000 \\
\frac{5000000-x_{1}}{3500000} & \rightarrow & 1500000 \leq x_{1} \leq 5000000
\end{array}\right.
\end{aligned}
$$

$$
\mu H \text { arg a }{ }_{\text {MAILAL }}\left[x_{1}\right]=\left\{\begin{array}{ccc}
1 & > & x_{1} \geq 5000000 \\
\frac{x_{1}-1500000}{3500000} & \rightarrow & 1500000<x_{1}<5000000 \\
0 & , & x_{1} \leq 500000
\end{array}\right.
$$

Misalnya ingin diketahui tipe HP apa saja yang harganya SEDANG, beratnya RINGAN, dan ada WAP. Maka, Structured Query Laguage (SQL) yang dibentuk adalah :

SELECT type FROM dt hp WHERE (harga = "SEDANG") AND (berat = "RINGAN") AND $(W A P=T R U E)$

Karena variabel WAP bersifat non fuzzy, maka hanya ada 2 kemungkinan derajat keanggotaan, yaitu 1 apabila ada WAP, dan 0 apabila tidak ada WAP. Tabel 2 memperlihatkan fire strength sebagai hasil operasi dari (Harga SEDANG) AND (Berat RINGAN) AND (Ada WAP) sebagai :

HargaSEDANG^BeratRINGAN^AdaWAP $=\min ($ HargaSEDANG[x1], BeratRINGAN[x3], AdaW

\begin{tabular}{|c|c|c|c|c|c|}
\hline \multirow[b]{3}{*}{ No. } & \multicolumn{5}{|c|}{ RINGAN, Ada WAP } \\
\hline & & Deraj & at Keanggo & taan & \\
\hline & Type & $\begin{array}{l}\text { Harga } \\
\text { SEDANG }\end{array}$ & \begin{tabular}{|c|} 
Berat \\
RINGAN
\end{tabular} & $\begin{array}{l}\text { Ada } \\
\text { WAP }\end{array}$ & Strength \\
\hline 1 & 6898 & 0,829 & 0,360 & 1 & 0,360 \\
\hline 2 & A3618 & 0,000 & 0,280 & 0 & 0,000 \\
\hline 3 & $\mathrm{C} 35$ & 0,200 & 0,000 & 1 & 0,000 \\
\hline 4 & $\mathrm{C} 45$ & 0,230 & 0,000 & 1 & 0,000 \\
\hline 5 & CL50 & 0,714 & 0,420 & 1 & 0,420 \\
\hline 6 & CMD J5 & 0,940 & 0,380 & 1 & 0,380 \\
\hline 7 & N3350 & 0,425 & 0,000 & 1 & 0,000 \\
\hline 8 & N5510 & 0,650 & 0,000 & 1 & 0,000 \\
\hline 9 & $\mathrm{~N} 8210$ & 0,914 & 0,420 & 1 & 0,420 \\
\hline 10 & N8910 & 0,000 & 0,000 & 1 & 0,000 \\
\hline 11 & SG 2000 & 0,714 & 0,600 & 1 & 0,600 \\
\hline 12 & T190 & 0,250 & 0,000 & 1 & 0,000 \\
\hline 13 & T20 & 0,300 & 0,000 & 0 & 0,000 \\
\hline 14 & T200 & 0,800 & 0,300 & 1 & 0,300 \\
\hline 15 & T29s & 0.400 & 0.100 & 1 & 0.100 \\
\hline
\end{tabular}
$\mathrm{AP}[\mathrm{x} 5])$

Tabel 2. Fire strength untuk query Harga SEDANG, Berat 
Tabel 2. memperlihatkan hasil pencarian terhadap Query 2. Ada 7 HP yang terekomendasi, dengan rekomendasi tertinggi adalah HP tipe SG 2000, dan rekomendasi terendah adalah HP tipe T29s. Sedangkan 8 tipe lainnya tidak direkomendasikan.

\section{Perumahan}

Menurut Undang-undang Nomor 4 Tahun 1992 (dalam sofyan [4]) tentang perumahan dan permukiman, perumahan adalah kelompok rumah yang berfungsi sebagai lingkungan tempat tinggal atau lingkungan hunian yang dilengkapi dengan prasarana dan sarana lingkungan. Permukiman adalah bagian dari lingkungan hidup di luar kawasan lindung, baik yang berupa kawasan perkotaan maupun perdesaan yang berfungsi sebagai lingkungan tempat tinggal atau lingkungan hunian dan tempat kegiatan yang mendukung perikehidupan dan penghidupan. Dalam proses pemilihan rumah , biasanya user akan menentukan pilihan berdasarkan harga rumah, uang muka yang harus dibayarkan, luas/tipe bangunan, luas tanah, lebar jalan, jarak rumah dengan jalan raya, jarak rumah dengan sarana umum seperti pasar, balai kesehatan[4].

\section{Bahasa Pemrograman PHP dan MySQL}

Menurut Firdaus [5] "Script PHP (PHP. Hypertext Preprocessor) merupakan bahasa web server-side yang bersifat open source. Bahasa PHP menyatu dengan script HTML yang sepenuhnya yang dijalankan pada server”. Program ini akan selalu membutuhkan sebuah server pendukung yang disebut Web Server dan program PHP itu sendiri untuk menjalankan semua script program. Sebagai bahasa pemrograman, PHP memiliki kelebihan, yaitu:

a. Bahasa pemrograman PHP adalah sebuah bahasa script yang tidak melakukan sebuah kompilasi dalam penggunaannya b. Dalam sisi pengembangan lebih mudah, karena banyaknya milis-milis dan developer yang siap membantu dalam pengembangan

c. Dalam sisi pemahaman, PHP adalah bahasa scripting yang paling mudah karena memiliki referensi yang banyak

Menurut Firdaus [5] "MySQL adalah database yang menghubungkan script PHP menggunakan perintah query dan escape character yang sama dengan PHP. Selain itu database ini memiliki kelebihan dibanding database lain, diantaranya adalah :

1. MySQL sebagai Database Management System (DBMS) dan Relation Database Management System (RDBMS)

2. MySQL adalah sebuah software database yang bebas digunakan siapa saja tanpa harus membeli dan membayar lisensi kepada pembuatnya.

\section{METODOLOGI}

Pada penelitian ini, peneliti menerapkan berbagai teori atau metode yang berkaitan dengan permasalahan yang diangkat. Beberapa teori yang terkait antara lain : teori logika fuzzy, database, metode database fuzzy model Tahani, bahasa pemrograman, dan lain-lain. Dengan adanya penerapan teori dan metode ini, maka diharapkan akan menjadi sistem aplikasi fuzzy database berbasis web yang dapat memberikan rekomendasi rumah sesuai dengan pertimbangan atau kriteriakriterianya dengan lebih cepat dan tepat.

\section{A. Teknik Pengumpulan Data}

Dalam mengumpulkan data, teknik pengumpulan data yang digunakan dalam penelitian ini yaitu: Observasi, Wawancara, Angket, Dokumentasi. 


\section{B. Metode Pengembangan Sistem}

Metode yang akan digunakan dalam pengembangan sistem adalah metode SDLC (Sistem Development Life Cycle) dengan menggunakan pendekatan waterfall. Disebut dengan waterfall karena tahap demi tahap yang dilalui harus menunggu selesainya tahap sebelumnya dan berjalan berurutan. Sehingga kelebihan model waterfall adalah menyediakan dokumentasi untuk tiap tahapan, tahapan sistematik, dan melakukan pemeriksaan keluaran setiap tahapan. Tahapan diagram Waterfall yang dilakukan adalah sebagai berikut [6] :
a. Requirements Analysis and Definition
b. System and Software Design
c. Implementation and Unit Testing
d. Integration and System Testing
e. Operation and Maintenance

\section{Diagram alir penelitian}

Adapun diagram alir pada penelitian ini dapat dilihat pada gambar 2. Tahapan penelitian dijelaskan sebagai berikut:

1. Pada tahap pertama adalah penentuan latar belakang masalah dari aplikasi yang akan dibuat. Sehingga akan diperoleh gambaran dan alasan kenapa aplikasi ini dibuat oleh peneliti.

2. Tahap kedua yaitu menentukan tujuan dan ruang lingkup penelitian. Dari tahapan ini peneliti akan mendapatkan gambaran tentang bagaimana metode fuzzy database model tahani ini dapat diaplikasikan sehingga diperoleh output yang dapat memberikan rekomendasi untuk konsumen dalam memilih rumah yang ingin dibeli, dan apa saja ruang lingkup yang membatasi peneliti dalam pengambilan data-data mengenai rumah nantinya.
3. Pada tahap ketiga dilakukan pengumpulan data-data yang diperlukan dalam penelitian, seperti data-data mengenai rumah dan parameter domain himpunan fuzzy. Untuk pengumpulan data-data tersebut akan diperoleh dari proses dokumentasi dan wawancara di PT. Cipta Graha Sentosa.

4. Tahap keempat akan dilakukan proses analisis kebutuhan. Analisis kebutuhan yang ditentukan oleh peneliti terdiri dari analisis kebutuhan sistem, analisis kebutuhan proses, analisis kebutuhan input, analisis kebutuhan output, dan analisis kebutuhan perangkat lunak dan perangkat keras.

5. Tahap kelima yaitu tahap perancangan fuzzy. Pada tahap ini akan dilakukan beberapa langkah yaitu pembentukan variabel fuzzy, himpunan fuzzy, domain himpunan fuzzy, fungsi keanggotaan fuzzy, dan komposisi aturan (operator himpunan fuzzy).

6. Tahap keenam yaitu perancangan Data Flow Diagram (DFD). Pada tahapan inilah nantinya akan diketahui semua entitas luar, input, dan output yang terlibat dalam sistem serta diagram konteks, diagram level satu dan dua yang digunakan dalam analisis sistem.

7. Tahap berikutnya yaitu perancangan Entity Relationship Diagram (ERD). Dalam perancangan tersebut akan dilakukan beberapa proses yaitu pembuatan tabel database dan perancangan relasi antar database. Sehingga dapat dijadikan sebagai dasar dari pembuatan perangkat lunak nantinya.

8. Pada tahap kedelapan akan dilakukan perancangan flowchart dan antarmuka (Human Interface). Tahap perancangan flowchart akan digunakan untuk menggambarkan sistem baru yang akan 
dikembangkan secar logis tanpa mempertimbangkan terlebih dahulu lingkungan sistem. Sedangkan tahap perancangan antarmuka akan dibuat dalam beberapa form yang memiliki user friendly sehingga bisa digunakan oleh orang awam.

9. Tahapan yang kesembilan ini adalah pembutan coding. Pada tahapan inilah akan dilakukan penggabungan antara hasil dari tahapan lima hingga delapan, yaitu dari tahapan perancangan fuzzy, DFD, ERD, flowchart dan antarmuka ke dalam sebuah pengkodean untuk menghasilkan sebuah program aplikasi.
10. Tahapan selanjutnya yaitu tahapan pengujian (testing) terhadap hasil program yang telah dibuat. Jika pada tahapan pengujian sistem aplikasi telah sesuai dengan perancangan sistem sebelumnya dan memiliki kinerja yang layak untuk digunakan oleh sistem maka tahapan akan diteruskan ke tahapan hasil dan kesimpulan, namun jika masih terdapat kesalahan pada sistem maka sistem segera diperbaiki.

Tahapan terakhir adalah membuat hasil dan kesimpulan. Tahap tersebut dilakukan untuk mengetahui hasil yang telah diperoleh dan masalah yang dihadapi selama pembutan program.
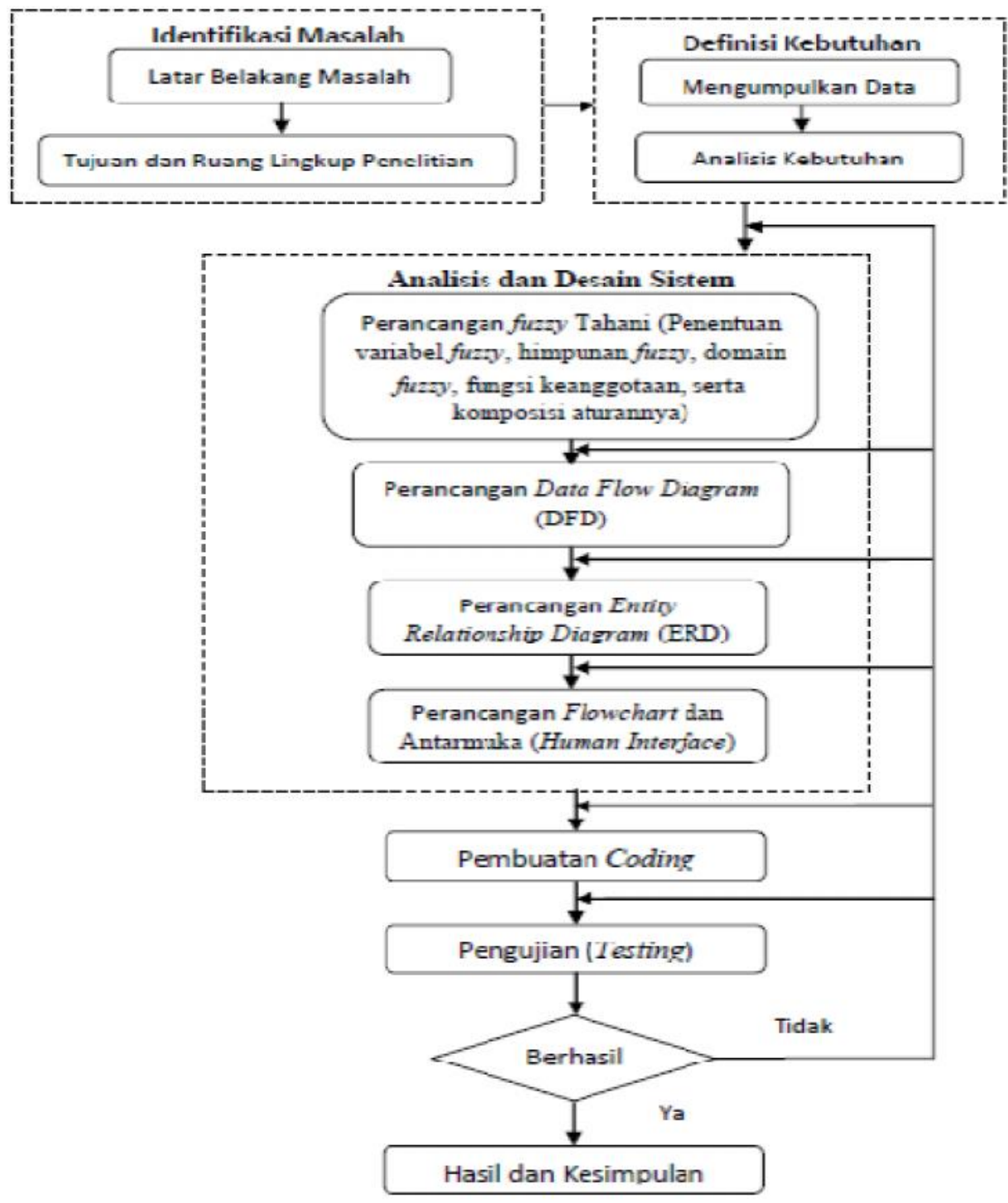

Gambar 2 Diagram Alir Penelitian 


\section{ANALISIS KEBUTUHAN SISTEM}

Analisis kebutuhan sistem meliputi :

1) Analisis Kebutuhan Masukan: Input atau masukan dari aplikasi basis data fuzzy model Tahani dalam memberikan rekomendasi pembelian rumah pada penelitian ini, terdiri atas dua yaitu :

a) Input Admin, merupakan suatu masukan yang diberikan oleh admin yakni berupa data user admin, data variabel, himpunan, perumahan, dan data rumah.

b) Input Pengunjung (konsumen), merupakan suatu masukan yang ditentukan oleh pengunjung (konsumen) yaitu kriteria rumah yang berupa pilihan dari beberapa variabel rumah beserta operator OR atau AND yang akan digunakan untuk proses pencarian rekomendasi rumah.

2) Analisis Kebutuhan Proses: Analisis kebutuhan proses merupakan semua proses yang akan dilakukan selama aplikasi basis data fuzzy model Tahani digunakan oleh pengunjung (konsumen) dan admin. Adapun proses-proses yang dilakukan dalam sistem aplikasi tersebut yaitu sebagai berikut :

a) Proses autentifikasi bagi admin

b) Proses penambahan, pengeditan, dan penghapusan variabel.

c) Proses penambahan, pengeditan, dan penghapusan himpunan fuzzy.

d) Proses penambahan, pengeditan dan penghapusan perumahan.

e) Proses penambahan, pengeditan, dan penghapusan data rumah.

Sedangkan proses yang terjadi di pengunjung (konsumen) yaitu sebagai berikut:

a) Proses pemilihan kriteria rumah sesuai dengan yang dicari. b) Proses pencarian hasil rekomendasi (query)

c) Proses penampilan detail rumah hasil rekomendasi kepada pengunjung (konsumen).

d) Proses penampilan informasi mengenai perumahan, data rumah, dan parameter.

3) Analisis Kebutuhan Keluaran. Adapun keluaran dari aplikasi rekomendasi pembelian rumah di PT. Cipta Graha Sentosa Bengkulu ini adalah berupa halaman web yang dapat digunakan pengunjung (konsumen) untuk melihat; a) Informasi mengenai rekomendasi rumah yang sesuai dengan pilihan pengunjung/ konsumen, b) Informasi detail rumah yang berupa atribut-atribut pada rumah tersebut, c) informasi perumahan, data rumah, dan parameter secara keseluruhan (variabel, himpunan, dan nilai domain fuzzy) juga didapatkan oleh konsumen dalam menu yang disediakan oleh web.

\section{4) Analisis Kebutuhan Perangkat lunak dan} Perangkat Keras. Dalam pembangunan sistem ini dibutuhkan beberapa perangkat lunak (software) yaitu sebagai berikut:

a. XAMPP versi 1.5.4 dan MySQL-Front Versi 5.0

b. Macromedia dreamweaver CS3

c. Sistem Operasi Windows 7

Sedangkan perangkat keras (hardware) yang dibutuhkan untuk pengembangan aplikasi ini adalah :

a. Laptop Acer Aspire 2930

b. Processor Intel Pentium core 2 duo T6400

c. Hardisk $250 \mathrm{~GB}$ dan Memory $2 \mathrm{~GB}$.

5) Analisis Perancangan Fuzzy Tahani. Perancangan fuzzy Tahani dilakukan dalam beberapa tahap yaitu: 

a) Penentuan Variabel Fuzzy;
b) Penentuan Himpunan Fuzzy;
c) Penentuan Domain Fuzzy;
d) Penentuan Fungsi Keanggotaan; dan
e) Penentuan Komposisi Aturan.

Penentuan jenis-jenis variabel dan himpunan fuzzy yang akan digunakan dalam aplikasi ini didasarkan pada hasil pengumpulan data di PT. Cipta Graha Sentosa Bengkulu. Proses penentuan variabel fuzzy ditentukan berdasarkan hasil wawancara dengan pihak PT. Cipta Graha Sentosa. Sedangkan proses penentuan domain (batasan range) himpunan fuzzy ditentukan berdasarkan hasil dari penyebaran angket secara langsung kepada beberapa pengunjung dan masyarakat di lingkungan sekitar. Adapun jenis-jenis variabel, himpunan fuzzy, fungsi keanggotaan, dan domain (batasan range) fuzzy dapat dilihat dengan jelas pada tabel 3 sebagai berikut ini:

\begin{tabular}{|c|c|c|c|c|}
\hline Variabel & $\begin{array}{c}\text { Himpunan } \\
\text { Fuzzy }\end{array}$ & $\begin{array}{c}\text { Fungsi } \\
\text { Keanggutaau }\end{array}$ & $\begin{array}{c}\text { Dumain } \\
\text { (Batasan Range) }\end{array}$ & Keterangan \\
\hline \multirow{3}{*}{ Harga } & Murah & Lincer Turun & {$[50,250]$} & \multirow{3}{*}{$\begin{array}{l}\text { Dalam juta } \\
\left.\text { |kupiah ('/ } \mathrm{K}_{\mathrm{p}}\right)\end{array}$} \\
\hline & Sedang & Seg.tiga & $\lfloor 100.500\rfloor$ & \\
\hline & Mahal & Linear Na1k & {$[300,600]$} & \\
\hline \multirow{3}{*}{$\begin{array}{l}\text { Uang, } \\
\text { Muka }\end{array}$} & Rendah & Lincer Turun & {$[30,70]$} & \multirow{3}{*}{$\begin{array}{l}\text { Dalam juta } \\
\left.\text { Rupiah ( } \mathrm{R}_{\mathrm{p}}\right)\end{array}$} \\
\hline & Sedang & Segitiga & $\lfloor 50,120]$ & \\
\hline & Tiuggi & Linear Naik & $\lceil 100,140\rceil$ & \\
\hline \multirow{2}{*}{$\begin{array}{c}\text { Luas } \\
\text { | 3angunan }\end{array}$} & Kccil & Lincer Turun & {$[20,50]$} & \multirow{2}{*}{$\begin{array}{c}\text { Dalam } \\
\text { meter } \\
\text { persegl }\left(\mathrm{m}^{2}\right)\end{array}$} \\
\hline & $\frac{\text { Sedang }}{\text { Lulas }}$ & $\begin{array}{c}\text { Segutga } \\
\text { Limear Naik }\end{array}$ & $\frac{[40,100]}{[80,120]}$ & \\
\hline \multirow{3}{*}{$\begin{array}{l}\text { I Mas } \\
\text { Tanah }\end{array}$} & Kccil & Lincar Turun & {$[80,120]$} & \multirow{3}{*}{$\begin{array}{c}\text { Dalam } \\
\text { meter } \\
\text { persegi }\left(\mathrm{m}^{2}\right)\end{array}$} \\
\hline & Sedang & Segitign & $[100,700)]$ & \\
\hline & Luas & Lmear Nalk & $\lfloor 170,240\rfloor$ & \\
\hline \multirow{3}{*}{$\begin{array}{r}\text { Lebar } \\
\text { Jalan1 }\end{array}$} & Kecil & Linear Turun & {$[2,5]$} & \multirow{3}{*}{$\begin{array}{c}\text { Dalam } \\
\text { meter }(m)\end{array}$} \\
\hline & Standar & Segitiga & {$[3,9]$} & \\
\hline & Besar & Linesr Naik & {$[7,11]$} & \\
\hline \multirow{3}{*}{$\begin{array}{c}\text { Jarak } \\
\text { numah } \\
\text { dari jalan } \\
\text { raya }\end{array}$} & Dekat & Linear Turun & {$[20,100]$} & \multirow{3}{*}{$\begin{array}{l}\text { Dalam } \\
\text { meter }(\mathrm{m})\end{array}$} \\
\hline & Sedang & Segitiga & {$[60,320]$} & \\
\hline & Jauh & Lincar Naik & {$[280,360]$} & \\
\hline
\end{tabular}

\section{HASIL DAN PEMBAHASAN}

\section{A. Hasil}

Berdasarkan tahapan pemrograman yang telah dilakukan maka dihasilkan tampilan sistem seperti pada gambar-gambar 3 berikut : a. Halaman utama

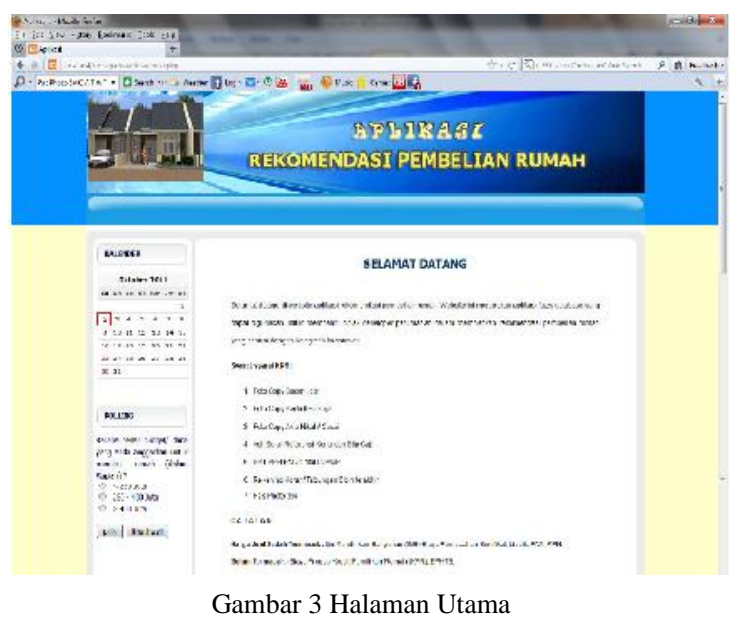

b. Halaman Proses Maintenance Variabel

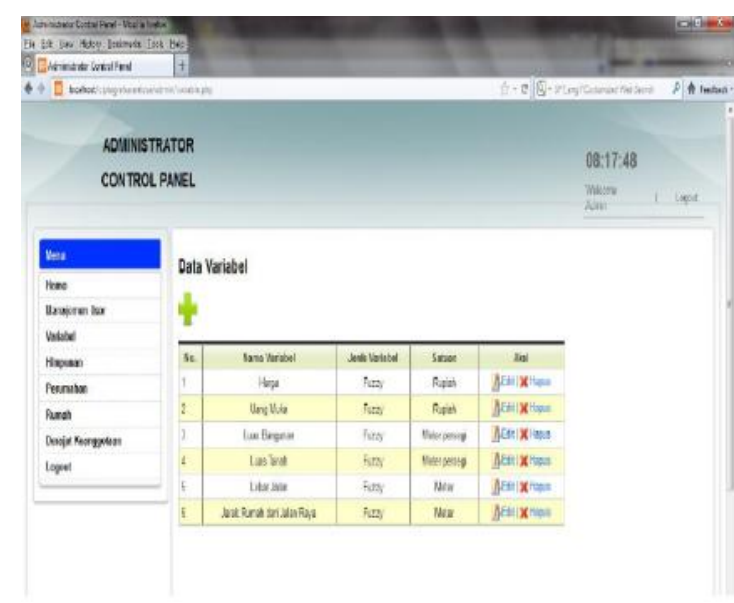

Gambar 4 halaman proses maintenance variabel

\section{c. Halaman Proses Maintenance Himpunan}

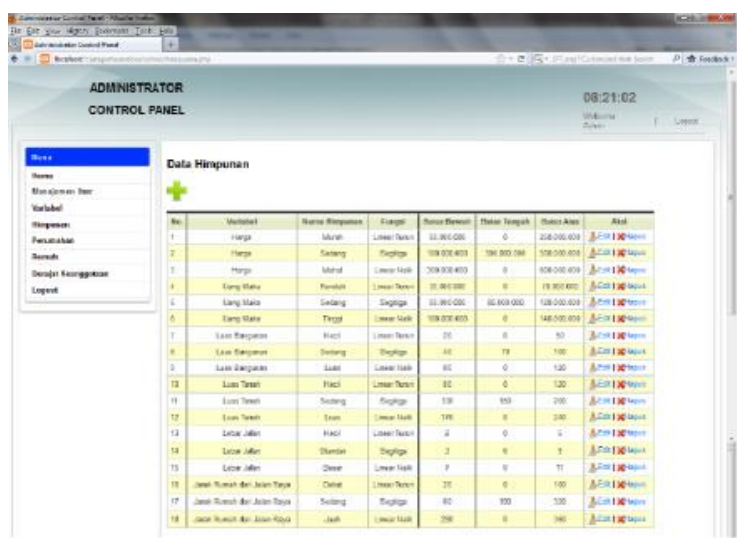

Gambar 5. Proses Maintenance Himpunan 
d. Halaman Proses Pengolahan Data Derajat Keanggotaan

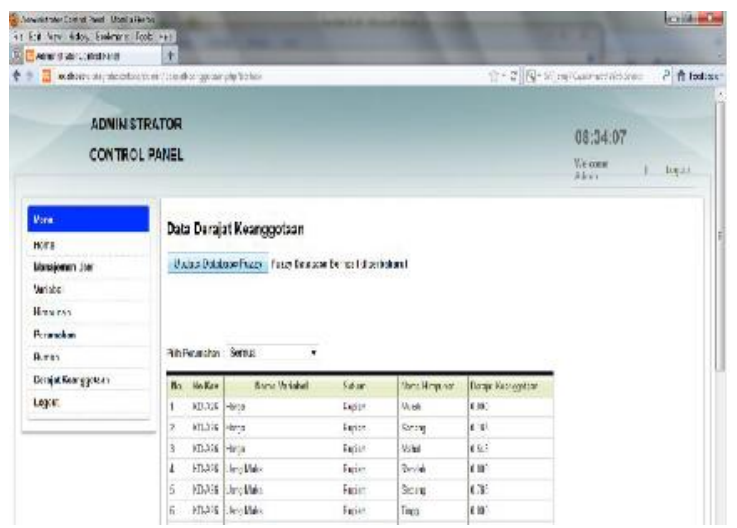

Gambar 6 Halaman Proses Pengolahan Data Derajat Keanggotaan

e. Halaman Proses Pencarian Rekomendasi

Rumah

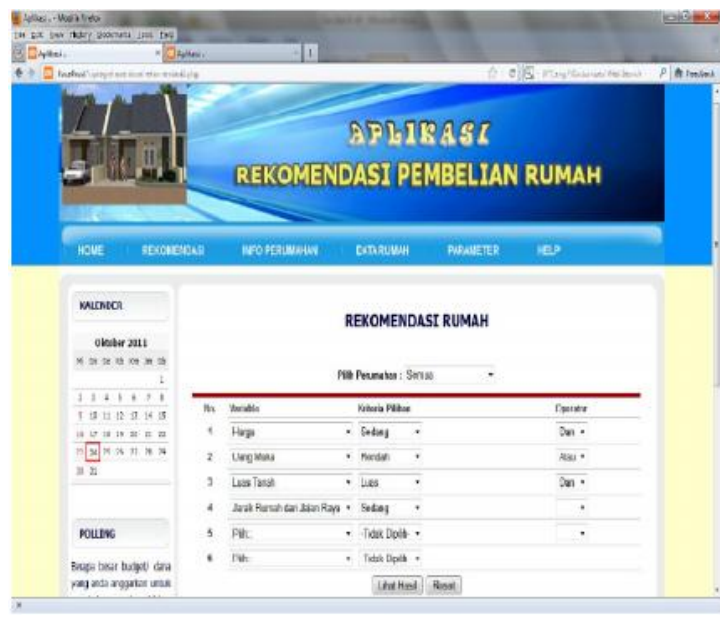

Gambar 7 Proses Pencarian Rekomendasi Rumah

f. Halaman Hasil Rekomendasi

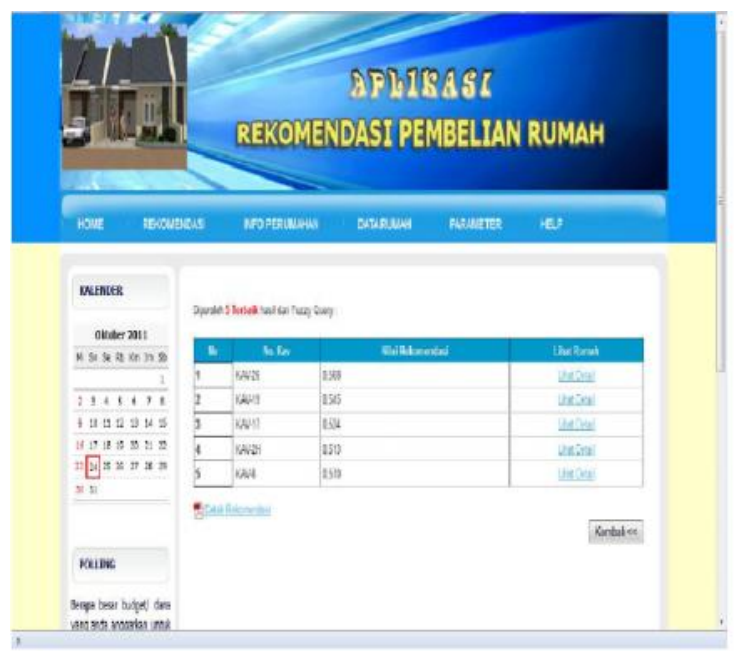

Gambar 8 Hasil Rekomendasi

\section{B. Pembahasan}

Pengujian sistem dilakukan dengan melakukan komparasi hasil perhitungan manual dengan hasil perhitungan yang dilakukaan oleh sistem. Hal ini bertujuan untuk menguji apakah aplikasi yang telah dibuat menghasilkan output yang sesuai dengan metode fuzzy database model Tahani. Pada percobaan ini, data rumah yang akan diuji sebanyak 43 rumah seperti yang terlihat pada Tabel 4 berikut :

Tabel 4. Data-data Rumah yang Akan Diuji

\begin{tabular}{|c|c|c|c|c|c|c|c|}
\hline No. & $\begin{array}{l}\text { Nomor } \\
\text { Kavling }\end{array}$ & Harga & Uang Mula & $\begin{array}{c}\text { Luas } \\
\text { Banguuan }\end{array}$ & $\begin{array}{l}\text { Luas } \\
\text { Tanah }\end{array}$ & $\begin{array}{l}\text { Lebar } \\
\text { Jalan }\end{array}$ & $\begin{array}{c}\text { Jarak } \\
\text { Rumah } \\
\text { dari } \\
\text { Jalan } \\
\text { Raya } \\
\end{array}$ \\
\hline 1 & KD-A26 & 463.000 .000 & 92.600 .000 & 60 & 276 & 10 & 1,25 \\
\hline 2 & KD-A27 & 418.000 .000 & 83.600 .000 & 60 & 253 & 10 & 1,25 \\
\hline 3 & KD-A28 & 349.000 .000 & 69.800 .000 & 60 & 184 & 10 & 1,25 \\
\hline 4 & KD-A29 & 349.000 .000 & 69.800 .000 & 60 & 184 & 10 & 1,25 \\
\hline 5 & KD-A30 & 349.000 .000 & 69.800 .000 & 60 & 184 & 10 & 1,25 \\
\hline 6 & KD-A31 & 465.000 .000 & 93.000 .000 & 60 & 300 & 10 & 1,25 \\
\hline 7 & KD-B17 & 281.000 .000 & 56.200 .000 & 60 & 153 & 7 & 125,68 \\
\hline 8 & KD-B18 & 250.000 .000 & 50.000 .000 & 60 & 119 & 7 & 133,83 \\
\hline 9 & KD-B19 & 250.000 .000 & 50.000 .000 & 60 & 119 & 7 & 141,83 \\
\hline 10 & KD-B20 & 250.000 .000 & 50.000 .000 & 60 & 119 & 7 & 149,83 \\
\hline 11 & KD-B21 & 250.000 .000 & 50.000 .000 & 60 & 119 & 7 & 157,83 \\
\hline 12 & KD-C6 & 258.000 .000 & 51.600 .000 & 60 & 132 & 10 & 149,73 \\
\hline 13 & KD-D3 & 250.000 .000 & 50.000 .000 & 60 & 119 & 10 & 120,25 \\
\hline 14 & KD-D5 & 250.000 .000 & 50.000 .000 & 60 & 119 & 10 & 128,25 \\
\hline 15 & KA-Al & 326.000 .000 & 97.800 .000 & 60 & 189 & 8 & 70,10 \\
\hline 16 & KA-A2 & 273.000 .000 & 81.900 .000 & 60 & 127 & 8 & 62,10 \\
\hline 17 & KA-AS & 273.000 .000 & 81.900 .000 & 60 & 127 & 8 & 57,10 \\
\hline 18 & KA-A9 & 273.000 .000 & 81.900 .000 & 60 & 127 & 8 & 65,10 \\
\hline 19 & KA-A10 & 288.000 .000 & 86.400 .000 & 60 & 144 & 8 & 73,10 \\
\hline 20 & KA-B1 & 342.000 .000 & 102.600 .000 & 60 & 207 & 8 & 91,10 \\
\hline 21 & KA-B2 & 273.000 .000 & 81.900 .000 & 60 & 127 & 8 & 83,10 \\
\hline 22 & KA-B3 & 273.000 .000 & 81.900 .000 & 60 & 127 & 8 & 75,10 \\
\hline 23 & KA-B5 & 273.000 .000 & 81.900 .000 & 60 & 127 & 8 & 61,10 \\
\hline 24 & KA-B10 & 287.000 .000 & 86.100 .000 & 60 & 143 & 8 & 79,1 \\
\hline 25 & KA-Cl & 326.000 .000 & 97.800 .000 & 60 & 189 & 8 & 124,3 \\
\hline 26 & KA-C2 & 273.000 .000 & 81.900 .000 & 60 & 127 & 8 & 116,3 \\
\hline 27 & $\mathrm{KA}-\mathrm{C} 3$ & 273.000 .000 & 81.900 .000 & 60 & 127 & 8 & 108,3 \\
\hline 28 & KA-C5 & 273.000 .000 & 81.900 .000 & 60 & 127 & 8 & 93,3 \\
\hline 29 & KAV-2H & 202.650 .000 & 40.530 .000 & 45 & 161 & 7,5 & 322,44 \\
\hline 30 & KAV-3 & 182.000 .000 & 36.400 .000 & 45 & 139 & 7,5 & 305,5 \\
\hline 31 & KAV-5 & 182.00 & 36.400 .000 & 45 & 139 & 7,5 & 295,5 \\
\hline 32 & KAV-6 & 189.500 .000 & 37.900 .000 & 45 & 154 & 7,5 & 347,94 \\
\hline 33 & KAV-7 & 181.500 .000 & 36.300 .000 & 45 & 138 & 7,5 & 285,5 \\
\hline 34 & KAV-8 & 202.000 .000 & 40.400 .000 & 45 & 179 & 7,5 & 313,44 \\
\hline 35 & KAV-10 & 193.000 .000 & 38.600 .000 & 45 & 161 & 7,5 & 304,4 \\
\hline 36 & KAV-12 & 194.500 .000 & 38.900 .000 & 45 & 164 & 7,5 & 293,94 \\
\hline 37 & KAV-15 & 178.000 .000 & 35.600 .000 & 45 & 131 & 7,5 & 287,5 \\
\hline 38 & KAV-17 & 206.850 .000 & 41.370 .000 & 45 & 169 & 7,5 & 297,5 \\
\hline 39 & KAV-19 & 209.000 .000 & 41.800 .000 & 45 & 193 & 7,5 & 285 \\
\hline 40 & KAV-20 & 202.000 .000 & 40.400 .000 & 45 & 179 & 7,5 & 294 \\
\hline 41 & KAV-22 & 184.500 .000 & 36.900 .000 & 45 & 144 & 7,5 & 330 \\
\hline 42 & KAV-25 & 187.000 .000 & 37.400 .000 & 45 & 149 & 7,5 & 339 \\
\hline 43 & KAV-26 & 213.500 .000 & 42.700 .000 & 45 & 202 & 7,5 & 348 \\
\hline
\end{tabular}

Untuk menguji sistem maka diberikan kasus sederhana yakni Ingin diketahui rumah apa saja yang ada pada semua perumahan yang memiliki kriteria harga "SEDANG" dan uang muka "RENDAH", atau luas tanah "LUAS" dan jarak rumah dari jalan raya "SEDANG". 
Berdasarkan nilai yang diperoleh dari perhitungan manual seperti yang terlihat pada tabel 5 dan Hasil pencarian Query secara Manual terlihat pada tabel 6.

Tabel 5 Fire Strength secara Manual

\begin{tabular}{|c|c|c|c|c|c|c|c|c|}
\hline \multirow[b]{2}{*}{ No. } & \multirow[b]{2}{*}{ No. $\mathrm{Kar}$} & \multicolumn{4}{|c|}{ Derajat Kaauggotaau } & \multicolumn{3}{|c|}{ Fire Streagth } \\
\hline & & $\begin{array}{c}\underset{\text { Harga }}{\text { HEDANG }} \\
\text { S(x) }\end{array}$ & $\begin{array}{c}\text { Unas } \\
\text { Muhi } \\
\text { KENDAH } \\
\left(I_{2}\right)\end{array}$ & $\begin{array}{l}\text { Luas } \\
\text { Taualh } \\
\text { LU:AS } \\
\left(x_{1}\right)\end{array}$ & $\begin{array}{c}\text { JRJR } \\
\text { SLDAVG } \\
\left(\mathbf{x}_{6}\right]\end{array}$ & $\begin{array}{l}I_{1} \hat{k} \\
I_{1} \hat{k} \\
(>1)\end{array}$ & $\begin{array}{l}x_{4} \& \\
x_{k} \\
(\mathbf{x} 2)\end{array}$ & $\begin{array}{l}21 \\
\text { OK } \\
22\end{array}$ \\
\hline 1 & $\mathrm{KD}-\mathrm{A} 26$ & 0.185 & $i^{-12}$ & 1 & 0 & 0 & 0 & 0 \\
\hline 2 & $\mathrm{KD}$ A.27 & 0,110 & 0 & 1 & 0 & 0 & 0 & 0 \\
\hline 3 & $\mathrm{KD}-\mathrm{A} 28$ & 0,755 & 0,005 & 0,200 & 0 & 0,005 & 0 & 0,005 \\
\hline 4 & $\mathrm{KD}-\mathrm{A} 29$ & 0,755 & 0,005 & 0,200 & 0 & 0,005 & 0 & 0,005 \\
\hline 5 & $\mathrm{KD}-A 30$ & 0,755 & 0,005 & 0,200 & 0 & 0,005 & 0 & 0,005 \\
\hline 6 & $\mathrm{KD}-\mathrm{h} 31$ & 0,175 & 0 & 1 & 0 & 0 & 0 & 0 \\
\hline 7 & $\mathrm{KD}-\mathrm{B} 17$ & 0,905 & 0,345 & 0 & 0,505 & 0,345 & 0 & 0,345 \\
\hline 8 & KD-B18 & 0.750 & 0,500 & 0 & 0,568 & 0,500 & 0 & $0,50)$ \\
\hline 9 & KD B19 & 0,750 & 0,500 & 0 & 0,629 & 0,500 & 0 & 0,500 \\
\hline 10 & $\mathrm{KD}-\mathrm{B} 20$ & 0,750 & 0,500 & 0 & 0,691 & 0,500 & 0 & 0,505 \\
\hline 11 & $\mathrm{KD}-\mathrm{B} 21$ & 0,750 & 0,500 & 0 & 0,753 & 0,500 & 0 & $0,50)$ \\
\hline 12 & KD-C6 & 0,790 & 0,460 & 0 & 0,690 & 0,460 & 0 & 0,167 \\
\hline 13 & $\mathrm{KD}-\mathrm{D} 3$ & 0,750 & 0,500 & 0 & 0,463 & 0,500 & 0 & 0,509 \\
\hline 14 & KD-DS & 0,750 & 0,500 & 0 & 0,525 & 0,500 & 0 & 0,500 \\
\hline 15 & $\mathrm{KA}-\mathrm{A1}$ & 0.870 & 0 & 0.271 & 0.078 & 0 & 0.078 & 0.073 \\
\hline 16 & $\mathrm{KA}$ A2 & 0,865 & 0 & 0 & 0,016 & 0 & 0 & 0 \\
\hline 17 & $\mathrm{KA}-\mathrm{A} 8$ & 0,365 & 0 & 0 & 0 & 0 & 0 & 0 \\
\hline 18 & KA-AY & $0,86)$ & 0 & 0 & 0,039 & 0 & 0 & 0 \\
\hline 10 & KA-A10 & 0,940 & 0 & 0 & 0.101 & 0 & 0 & 0 \\
\hline 20 & $\mathrm{~K} \wedge-31$ & 0,790 & 0 & 0,529 & 0,239 & 0 & 0,239 & $0,23)$ \\
\hline 21 & KA-32 & 0,865 & 0 & 0 & 0,178 & 0 & 0 & 0 \\
\hline 22 & K4.33 & 0.865 & D & 0 & 0.116 & 0 & 0 & 0 \\
\hline 23 & KA.35 & 0,865 & 0 & 0 & 0,008 & 0 & 0 & 0 \\
\hline 24 & KA-B10 & 0,935 & 0 & 0 & 0,147 & 0 & 0 & 0 \\
\hline 22 & KA-C1 & $0,8 / 0$ & 0 & $0,2 / 1$ & 0,493 & 0 & $0,2 / 1$ & 0,271 \\
\hline 26 & $\mathrm{~K}_{4} \mathrm{C}_{2}$ & 0.865 & 0 & 0 & 0433 & 0 & 0 & 0 \\
\hline 27 & $\mathrm{~K} \Lambda-\mathrm{C} 3$ & 0,865 & 0 & 0 & 0,372 & 0 & 0 & 0 \\
\hline 28 & KA-C5 & 0,865 & 0 & 0 & 0,256 & 0 & 0 & 0 \\
\hline 29 & $\mathrm{~K} A \mathrm{~V}-2 \mathrm{H}$ & 0.513 & 0.737 & 0 & 0 & 0.513 & 0 & 0.513 \\
\hline 30 & KAV-3 & 0,410 & 0,840 & 0 & 0,112 & 0,410 & 0 & 0,410 \\
\hline 31 & KAV-5 & 0,410 & 0,840 & 0 & 0,188 & 0,410 & 0 & 0,410 \\
\hline 32 & $\mathrm{KAV}-6$ & 0,448 & 0,803 & 0 & 0 & 0,448 & 0 & 0,445 \\
\hline 33 & KAV-7 & 0.408 & 0,843 & 0 & 0.265 & 0.408 & 0 & 0,403 \\
\hline 31 & KAV \& & 0,510 & 0,710 & 0,129 & 0,05 & 0,510 & 0,05 & 0,513 \\
\hline 35 & KAV-10 & 0,465 & 0,785 & 0 & 0,12 & 0,465 & 0 & 0,465 \\
\hline 36 & KAV-12 & $0,4 / 3$ & $0,7 / 8$ & 0 & 0.2 & $0.4 / 3$ & 0 & 0,473 \\
\hline 37 & KAV-15 & 0,390 & 0,860 & a & $0 \% 5$ & 0,390 & 0 & $0,39)$ \\
\hline 38 & $\mathrm{~K} / \mathrm{V}-17$ & 0,534 & 0,716 & 0 & 0,173 & 0,534 & 0 & 0,534 \\
\hline 39 & KAV-19 & 0,545 & 0,705 & 0,329 & 0,269 & 0,545 & 0,269 & 0,545 \\
\hline 40 & KAV-20 & 0.510 & 0,740 & 0,129 & 0.2 & 0.510 & 0.125 & 0,510 \\
\hline 41 & KAV-22 & 0,423 & 0,828 & 0 & 0 & 0,423 & 0 & 0,123 \\
\hline 42 & KAV-25 & 0,435 & 0,815 & 0 & 0 & 0,435 & 0 & 0,435 \\
\hline 45 & $\mathrm{~K} A \mathrm{~V}-26$ & 0,868 & 0,683 & $0,4) /$ & 0 & 0,068 & 0 & 0,563 \\
\hline
\end{tabular}

Tabel 6 Hasil pencarian Query secara Manual

\begin{tabular}{c|c|c||}
\multirow{2}{*}{ No. } & No. Kav & \multicolumn{2}{|c||}{ Nilai Rekomendasi } \\
\hline 1 & KAV-26 & 0,568 \\
\hline 2 & KAV-19 & 0,545 \\
\hline 3 & KAV-17 & 0,534 \\
\hline 4 & KAV-2H & 0,513 \\
\hline 5 & KAV-8 & 0,51 \\
\hline 6 & KAV-20 & 0,51 \\
\hline 7 & KD-B18 & 0,5 \\
\hline 8 & KD-B19 & 0,5 \\
\hline 9 & KD-B20 & 0,5 \\
\hline 10 & KD-B21 & 0,5 \\
\hline 11 & KD-D3 & 0,5 \\
\hline 12 & KD-D5 & 0,5 \\
\hline 13 & KAV-12 & 0,473 \\
\hline 14 & KAV-10 & 0,465 \\
\hline 15 & KD-C6 & 0,46 \\
\hline 16 & KAV-6 & 0,448 \\
\hline 17 & KAV-2) & 0,453 \\
\hline 18 & KAV-22 & 0,423 \\
\hline 19 & KAV-3 & 0,41 \\
\hline 20 & KAV-5 & 0,41 \\
\hline 21 & KAV-7 & 0,408 \\
\hline 22 & KAV-15 & 0,39 \\
\hline 23 & KD-B17 & 0,345 \\
\hline 24 & KA-C1 & 0,71 \\
\hline 25 & KA-B: & 0,239 \\
\hline 26 & KA-A1 & 0,078 \\
\hline 27 & KD-A28 & 0,005 \\
\hline 28 & KD-A29 & 0,005 \\
\hline 29 & KD-A30 & 0,005 \\
\hline & & \\
\hline
\end{tabular}

Berdasarkan Tabel 6 diperoleh hasil pencarian terhadap Query. Ada 29 rumah yang terekomendasi, sedangkan 14 rumah lainnya memiliki nilai rekomendasi 0 sehingga tidak direkomendasikan. Sedangkan hasil perhitungan melalui sistem terlihat pada gambar berikut :

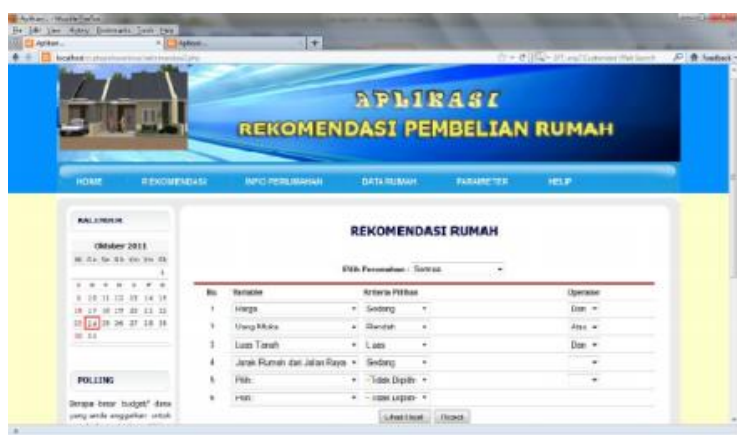

Gambar 9 Hasil Perhitungan Melalui Sistem

Dengan kriteria-kriteria rumah yang telah dipilih di atas, maka diperoleh 5 terbaik hasil dari fuzzy query, dengan nilai rekomendasi tertinggi pada rumah bernomor kavling KA-C1 sebesar 0,271 , dan nilai rekomendasi terendah pada rumah bernomor kavling KA-A1 sebesar 0,076. Hasil perhitungan tersebut dapat dilihat pada Gambar 10:

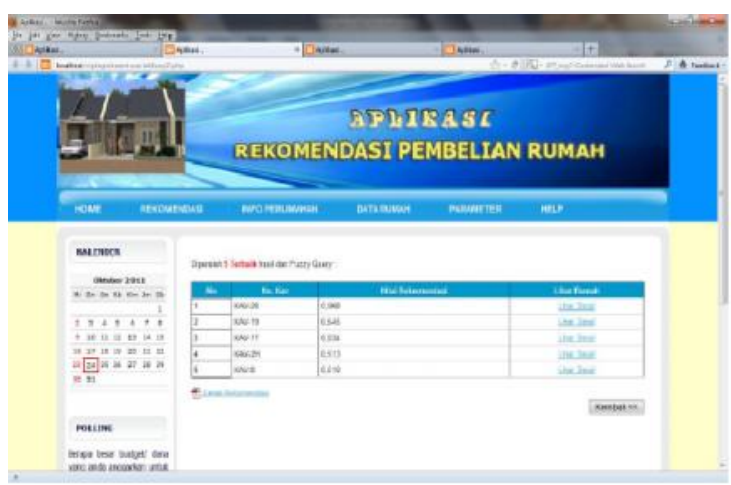

Gambar 10 Tampilan Hasil Rekomendasi Rumah

Tabel 7 Perbandingan Nilai Hasil Rekomendasi pada pengujian terhadap Perhitungan Manual dan Aplikasi

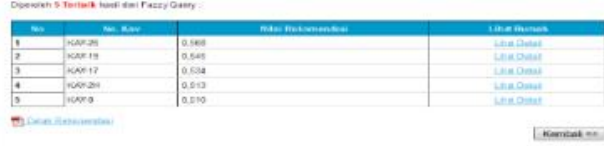

\begin{tabular}{|c|c|c|}
\hline No. & No. Kav & Nilai Rekomendasi \\
\hline 1 & KAV-26 & 0,568 \\
\hline 2 & KAV-19 & 0,545 \\
\hline 3 & KAV-17 & 0,534 \\
\hline 4 & KAV-2H & 0,513 \\
\hline 5 & KAV-8 & 0,51 \\
\hline
\end{tabular}


Dengan pembulatan 3 desimal dibelakang koma, untuk perhitungan menggunakan aplikasi dan manual dihasilkan 5 nilai terbaik dari yang tertinggi hingga terendah yaitu KA-C1 sebesar 0,271, KAV-19 sebesar 0,269, KA-B1 sebesar 0,239, KAV-20 sebesar 0,129, dan KA-A1 sebesar 0,078. Sehingga dapat disimpulkan bahwa aplikasi fuzzy database dalam memberikan rekomendasi rumah ini telah benar. Hal ini terlihat dari hasil output pada perhitungan dengan menggunakan aplikasi sama dengan hasil perhitungan manual.

\section{KESIMPULAN DAN SARAN}

\section{A. Kesimpulan}

Berdasarkan analisa perancangan sistem, implementasi dan pengujian sistem, maka dapat disimpulkan bahwa :

1. Metode fuzzy database model Tahani dapat digunakan dalam memberikan rekomendasi pembelian rumah.

2. Penelitian ini mampu menangani kriteriakriteria pembelian rumah yang bersifat samar.

3. Aplikasi fuzzy database model Tahani berbasis web yang dapat membantu pihak developer dalam memberikan rekomendasi rumah kepada konsumen sesuai dengan kriteria rumah yang diinginkan konsumen. Adapun hasil output dari aplikasi berupa maksimal 5 rumah terbaik yang memiliki nilai rekomendasi tertinggi berdasarkan perhitungan fire strength dari beberapa variabel pilihan yang telah ditentukan konsumen. Aplikasi yang dibangun juga dapat menghasilkan secara detail data rumah yang direkomendasikan, sehingga konsumen memperoleh informasi yang jelas mengenai spesifikasi yang dimiliki oleh rumah tersebut.

\section{B. Saran}

Pelaksanaan peneltian ini hanya terbatas pada data-data rumah yang telah diperoleh sebelumnya, variabel, nilai-nilai dari batas himpunan variabel hanya diperoleh berdasarkan observasi dan angket yang peneliti lakukan. Oleh karena itu, peneliti menyarankan agar aplikasi ini dapat terus dikembangkan lebih lanjut baik dalam hal penentuan variabel, dan nilai batasan domain himpunan fuzzy. Hal ini dikarenakan pada aplikasi yang dibangun, nilai batasan setiap himpunan masing-masing variabel belum bisa ditentukan oleh pengunjung secara langsung, namun baru ditentukan dari pihak developer. Dengan adanya saran ini, diharapkan agar aplikasi pemberian rekomendasi pembelian rumah yang akan dibangun selanjutnya bisa lebih baik lagi.

\section{REFERENSI}

[1] Kusumadewi, Sri. 2003. Artificial Intelligence (Teknik dan Aplikasinya). Yogyakarta : Graha Ilmu.

[2] Kusumadewi, Sri.2002. Analisis dan desain Sistem Fuzzy menggunakan Toolbox Matlab, Yogyakarta : Graha Ilmu.

[3] Kusumadewi, Sri dan Hari Purnomo. 2004. Aplikasi Logika Fuzzy Untuk Pendukung Keputusan. Yogyakarta : Graha Ilmu.

[4] Sofyan, Muhammad. 2011. Tingkat Kesesuaian Pembangunan Real Estate di Kota Bengkulu dengan Konsep Rumah Tahan Gempa. Fakultas Teknik Universitas Bengkulu : Skripsi Tidak Diterbitkan.

[5] Firdaus. 2007. PHP \& MySQL dengan Dreamweaver. Palembang : Maxikom.

[6] Jogiyanto. 2005. Analisis dan Desain Sistem Informasi: Pendekatan Terstruktur Teori dan Praktik Aplikasi Bisnis. Yogyakarta: ANDI 